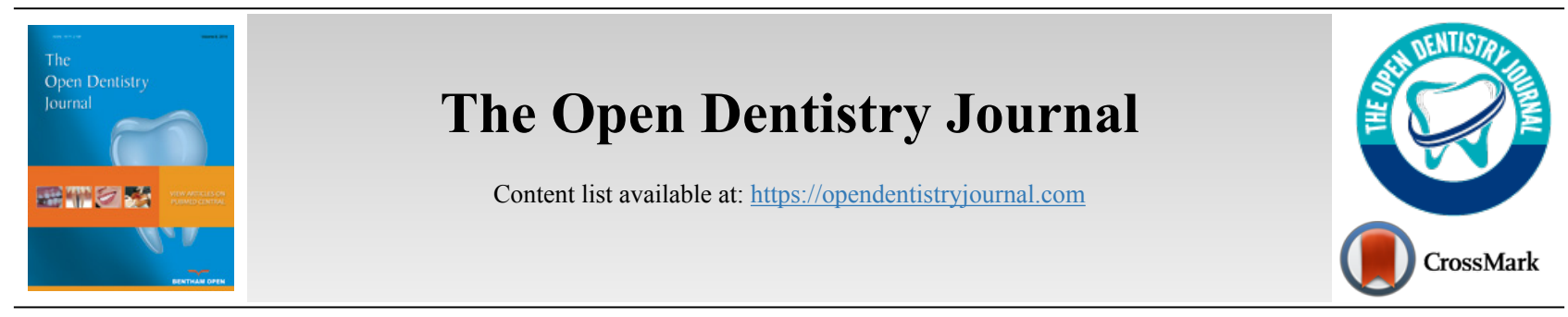

\title{
MINI-REVIEW
}

\section{Flipped Classroom Experiences in Clinical Dentistry - A Strategic Mini-Review}

\author{
Abdullah Aljabr ${ }^{1, *}$ \\ ${ }^{I}$ Department of Medical Education, College of Dentistry, Majmaah University, Al-Majmaah 11952, Saudi Arabia
}

\begin{abstract}
:
Background:

Pedagogy in dental education has evolved over the decades. Today, many alternative modes of content delivery are being used as an adjunct to the traditional classroom. A flipped classroom is one among those that are being explored for teaching clinical dentistry.

Objective:

This mini-review is aimed at evaluating the available evidence in the efficacy of flipped classrooms and its related aspects in the learning curve of clinical dentistry.

Methods:

A thorough literature search on electronic databases for all the studies focusing on the following evidence-based question: "Is Flipped classroom in clinical dentistry a useful mode of pedagogy delivery? was performed. A combination of MeSH terms using Boolean operators "AND," "OR:" FLIPPED [All Fields] AND ("dental health services" [MeSH Terms] AND "health" [All Fields] AND "services" [All Fields]) OR "dental" [All Fields]) AND ("learning" [MeSH Terms] OR "learning" [All Fields]). Specific terms such as "Perio" OR "Prostho" OR "Restorative" OR "Ortho" OR "Oral medicine" OR "Maxillofacial surgery" OR "Pediatric" OR "endo" was also used. Data from these articles addressing the aim of this study was extracted.
\end{abstract}

Results:

A total of 16 articles were considered for the review. The majority of the studies considered flipped classroom as a successful model of pedagogy. The most common mode of outside classroom activity was pre-recorded videos. In-classroom activities, a combination of seminars, interactive discussions, and quiz were explored. Time constraints, lack of faculty development programs are considered to be negative factors for the success of the flipped classroom.

Conclusion:

Within the limitation of the study, flipped classroom can be adapted as a method of pedagogy in clinical dentistry.

Keywords: Flipped classroom, Traditional classroom, Dentistry, Clinical, Review, Flipped learning, Pedagogy.

\begin{tabular}{|l|l|l|l|}
\hline Article History & Received: July 24, 2021 & Revised: September 28, 2021 & Accepted: October 26, 2021
\end{tabular}

\section{INTRODUCTION}

The last two decades have seen a considerable change in the pedagogical delivery in dental and medical education [1]. Traditional classroom (TC) is replaced, though not completely by other innovative methods of teaching and learning. In traditional classroom, delivery of content occurs through a lecture to a large group of students, usually with a PowerPoint presentation [2]. This teacher-centered mode of pedagogy deli-

* Address correspondence to this author at the Department of Medical Education College of Dentistry, Majmaah University, AL-Majmaah 11952, Saudi Arabia; Tel: +966555122114; Fax: +9660164227184; E-mail: aa.jabr@mu.edu.sa very does not involve the active participation of students and largely depends on the teacher in the lecture [3]. It is also a known fact that the concentration of the student can be maintained steadily in a lecture only for the first fifteen minutes [4], which will have a negative impact on understanding the key concepts, since the heart of the lecture may begin only after 15 minutes in a $45 \mathrm{~min}$ to one hour period. Dentistry is a blend of both engineering and medicine, where the dominance of cognitive skill is seen throughout the course. Achieving this skill is possible only with the practice, adopting active learning strategies and critical thinking capacity [5]. Further, understanding the theoretical concept 
with a diverse learning style is expected to enhance the practice of dentistry, like in any other health professional course [6]. To accomplish this, several alternative/blended learning strategies like problem-based learning, (PBL), case-based learning, (CBL), group-based or team-based learning, (TBL), and flipped classroom (FC) methods of innovative teaching have emerged and, to an extent, filled the learning gap seen with the traditional classroom [7]. The blended learning approach have an advantage of both old and new methods of the learning process and may overcome many hurdles of TC [8]. A flipped learning is a novice approach towards learning, where greater emphasis is placed upon the higher order of cognitive thinking. Here, the process of teaching-learning is inverted, where content (resources like PowerPoint presentation, video, or others) is provided to the students before the actual class and active learning is done during the routine class hours [9]. The difference between the FC and TC has been listed in Table 1 [10]. In dentistry, the use of an alternative method of learning is nothing new. FC as an alternative method for traditional classroom is discussed in original papers and reviews [11, 12]. Reviews available to date combined both pre-clinical and clinical dentistry [13, 14]. Since clinical dentistry and its importance in the lifetime practice of dentistry are always discussed in terms of confidence of individual student capability [15]. It is necessary to see how this content is delivered to them and how far this content delivery will be helpful when a new method of delivery is employed. To date, there are no exclusive reviews available on the use of flipped classroom in clinical dentistry. Gathering this information is essential to improve the FC experience in clinical dentistry. A mini-review in this regard is useful and may act as a guiding source for many clinical dentistry courses followed hereafter. Thus, this review is aimed at reviewing all studies available to date and to explore the use of FC in clinical dentistry.

\section{MATERIALS AND METHODS}

This review was intended to do in line with that of a systematic review or scoping review. Our objective was to explore the studies performed to date, then that of writing a general review article. Thus, we focused our literature search on a systematic manner. This mini-review was focused on the following evidence-based question: "Is Flipped classroom in clinical dentistry a useful mode of pedagogy delivery? Key factors and questions answered while concluding the answer for the focused question was, which mode of "out of the classroom activity" is suitable? which "in-classroom activity" is preferred for the FC? what "advantages and disadvantages" are pointed out? what is "student and faculty feedback including satisfaction"? are the studies considered in this review is sufficient to draw the above conclusion? (Bias in studies)

\subsection{Search Strategy}

To address the focused primary and secondary questions, a literature search was performed on electronic databases (PubMed, Scopus, and Google Scholar) for 3 months from Jan 2021 to March 2021. Though it was not a systematic review, we wanted to include all the possible publications. A search strategy on PubMed was built through a combination of MeSH terms using Boolean operators "AND," "OR:” FLIPPED[All Fields] AND ("dental health services" [MeSH Terms] OR ("dental"[All Fields] AND "health" [All Fields] AND "services" [All Fields]) OR "dental health services" [All Fields] OR "dental" [All Fields]) AND ("learning" [MeSH Terms] OR "learning" [All Fields]). Specific terms such as "Perio" OR "Prostho" OR "Restorative" OR "Ortho" OR "Oral medicine" OR "Maxillofacial surgery" OR "Pedo" OR "Pediatric" OR "dentistry" OR "endo" was also used. The search strategy was then adapted for other databases. In addition, reference lists of extracted articles were further screened, and a gray literature search was performed to find any missing studies. The articles were then imported into reference manager software and duplicates were removed.

\subsection{Study Selection Process}

\subsubsection{Inclusion Criteria}

1. Studies must have been published in English.

2. All the studies where "flipped classroom used in clinical dentistry" was considered.

3. Both didactic and clinical components were included

\section{Table 1. Traditional classroom vs flipped classroom.}

\begin{tabular}{|c|c|}
\hline Traditional Classroom & Flipped Classroom \\
\hline Delivered content through lecture in the class. & Inverted process with content delivered before the actual classroom. \\
\hline Teacher centered - teacher instructs at classroom & Student centered - teacher instructs at home (video/podcast/book/website) \\
\hline Students takes notes in the class and homework & $\begin{array}{l}\text { Students work in the class - with deeper understanding of the concept with assistance } \\
\text { from faculty }\end{array}$ \\
\hline Utilizes cognitive learning theory & Based on behaviorism \\
\hline $\begin{array}{l}\text { Students }{ }^{\text {' }} \text { ability to concentrate and focus begins to fade after } \\
\text { approximately ten to fifteen minutes }\end{array}$ & $\begin{array}{l}\text { Actively engage students during class with a } \\
\text { variety of activities that relate to the previous homework assignment- focus for longer } \\
\text { periods of time allowing for increased retention }\end{array}$ \\
\hline $\begin{array}{l}\text { Students only retain about } 20 \% \text { of the information taught in } \\
\text { traditional lecture style }\end{array}$ & Tend to retain more due to active engagement. \\
\hline $\begin{array}{l}\text { No critical thinking, complex reasoning skills, or effective } \\
\text { retention of information }\end{array}$ & $\begin{array}{l}\text { Allows critical thinking and problem/doubt solving through group discussion and } \\
\text { faculty assistance. }\end{array}$ \\
\hline $\begin{array}{l}\text { No one to one attention, difficult to assist who are weak in } \\
\text { their concepts. unless student approach individually }\end{array}$ & $\begin{array}{c}\text { Faculty can assist the students who are struggling, one-on-one attention, and } \\
\text { encourage students to be in charge of their learning }\end{array}$ \\
\hline
\end{tabular}




\subsubsection{Exclusion Criteria}

1. Papers published in other languages and translation not available.

\section{Pre-clinical and postgraduate studies}

3. Only online classes (which do not fit into the definition of the flipped classroom) and in the absence of face-to-face classes.

\subsection{Study Selection}

After the removal of duplicate studies, the titles and abstracts of all extracted articles were screened and subjected to the inclusion and exclusion criteria to perform preliminary elimination of ineligible studies. Following this, the full text of the articles was obtained and evaluated for inclusion in the mini-review. Any duplication of data presented in studies was noted.

\subsection{Data Extraction}

Data extraction was carried out using customized data retrieval forms. Extracted data included author, year, country, FC compared to other methods, outside classroom activity, inclassroom activity, specialty, number of students (cases and controls, major outcome/results, and conclusion/suggestions to improve. Key findings and other relevant information were also collected.

\section{RESULTS}

\subsection{Study Characteristics}

The flipped classroom was introduced between 2009 to 2014, with the first publication that can be traced to the year 2009. Among these, the number of research publications related to FC in dentistry was quite impressive (around 50 to
60), which shows that, like all other education systems, dental education too, is not far behind in introducing the newer innovative educational methods. Clinical dentistry application of flipped classroom was seen in a total of 16 studies, all of which are included in this review. There were studies related to FC every year from 2012 to 2021, except between (20132015). If we consider the publication per year, 2012(1), 2016(2), 2017(3), 2018(3), 2019 (2), 2020(3), and till March 2021 (2) were considered. Studies were performed in different countries listed as; 5 studies from the USA, 2 studies each from the Kingdom of Saudi Arabia and the United Kingdom, and 1 study each from Greece, Canada, Jordan, Germany, Sweden, Korea, and Japan. 9 of 16 studies compared FC with TC, 1 study compared with TBL (Team-based learning), remaining 6 studies used FC as a sole method of teaching and utilized students' previous experience of TC in the study.

\subsection{Flipped Classroom as an Effective Mode of Delivery - Focused Primary Question}

This is the focused primary question of the review. 10 out of 16 studies showed favorable results for the FC [16 - 29]. Favorable or success rate of the FC was measured in terms of student performance after exposure to FC. Results of the quiz and post-test done were better among the students exposed to FC. In addition to this, student satisfaction and feedback were positive $[17-19,22]$. This result was seen in relation to all forms of clinical exposure, from diagnosis to medical emergencies to routine clinical procedures. However, 6 out of 16 studies have shown that the perception of students to FC was reserved/ not superior to another form of blended learning like TBL $[11,12,20,21,23,24]$. It was also reflected in their test scores which were the same as that of the traditional classroom. In 2 of the studies, though the performance of the students in FC was the same as that of TC, student feedback about FC was encouraging [12, 24] (Table 2).

Table 2. Flipped class room details - outcome.

\begin{tabular}{|c|c|c|c|c|c|c|c|}
\hline Author & Control & $\begin{array}{c}\text { Out of } \\
\text { Classroom } \\
\text { Method }\end{array}$ & $\begin{array}{c}\text { In Class Time } \\
\text { Method }\end{array}$ & Specialty & $\begin{array}{c}\text { Number } \\
\text { of } \\
\text { Subjects }\end{array}$ & Outcome/Results & Suggestions/Conclusion \\
\hline $\begin{array}{c}\text { Kavadella } \\
2012 \\
\text { Greece [16] }\end{array}$ & $\begin{array}{l}\text { Traditional } \\
\text { classroom }\end{array}$ & $\begin{array}{l}\text { online exact } \\
\text { material }\end{array}$ & Quiz & Oral radiology & $\begin{array}{c}\text { Total } 47 \\
\text { FC- } 24 \\
\text { TC- } 23\end{array}$ & \begin{tabular}{|} 
Post test results \\
showed better with \\
Flipped classroom \\
students. \\
Mean self- \\
assessment grade for \\
FC was 6.21 and for \\
TC was 3.27. \\
$90.9 \%$ believed that \\
blended learning is \\
more effective than \\
traditional before the \\
course and $87.5 \%$ \\
believed the same \\
after the course. \\
$90.9 \%$ and $91.7 \%$ \\
(before and after) \\
believed that blended \\
learning motivates \\
students more than \\
traditional
\end{tabular} & $\begin{array}{l}\text { Time concern - is the major } \\
\text { drawback of the FC. } \\
\text { student free time was lesser } \\
\text { with the FC }\end{array}$ \\
\hline
\end{tabular}




\begin{tabular}{|c|c|c|c|c|c|c|c|}
\hline Author & Control & $\begin{array}{c}\text { Out of } \\
\text { Classroom } \\
\text { Method }\end{array}$ & $\begin{array}{l}\text { In Class Time } \\
\text { Method }\end{array}$ & Specialty & $\begin{array}{c}\text { Number } \\
\text { of } \\
\text { Subjects }\end{array}$ & Outcome/Results & Suggestions/Conclusion \\
\hline $\begin{array}{c}\text { Custer } 2016 \\
\text { USA [17] }\end{array}$ & $\begin{array}{l}\text { Traditional } \\
\text { classroom }\end{array}$ & Online material & $\begin{array}{l}\text { Pre and Post } \\
\text { test }\end{array}$ & Oral radiology & 17 & $\begin{array}{c}\text { All the students } \\
\text { found flipped } \\
\text { learning to be } \\
\text { effective; more than } \\
90 \% \text { believed it was } \\
\text { a better way to } \\
\text { prepare them for a } \\
\text { health care } \\
\text { profession }\end{array}$ & $\begin{array}{c}\text { FC is effective in learning } \\
\text { oral radiology. }\end{array}$ \\
\hline $\begin{array}{c}\text { Bohaty SB et al. } \\
2016 \\
\text { USa [11] }\end{array}$ & $\begin{array}{l}\text { Traditional } \\
\text { classroom }\end{array}$ & $E$ - lectures & $\begin{array}{l}\text { Discussion and } \\
\text { quiz }\end{array}$ & $\begin{array}{l}\text { Pediatric } \\
\text { dentistry }\end{array}$ & $\begin{array}{c}106 \\
\text { students }\end{array}$ & $\begin{array}{c}\text { Striking } \\
\text { improvement in the } \\
\text { grades earned by } \\
\text { students in the } \\
\text { flipped classroom. } \\
\text { design }\end{array}$ & $\begin{array}{l}\text { Ambiguity regarding. } \\
\text { their overall satisfaction } \\
\text { with the flipped classroom } \\
\text { design. }\end{array}$ \\
\hline $\begin{array}{c}\text { Zain-Alabdeen } \\
\text { EH } \\
2017 \\
\text { Saudi Arabia } \\
{[18]}\end{array}$ & - & $\begin{array}{l}\text { Video lecture of } \\
30 \mathrm{~min}\end{array}$ & $\begin{array}{l}\text { Exercise, } \\
\text { questions and } \\
\text { Group } \\
\text { discussion }\end{array}$ & Oral radiology & 50 & $\begin{array}{c}\text { FC provides more } \\
\text { time for questions } \\
\text { and discussions } \\
(60 \%) \\
\text { students were } \\
\text { motivated to learn } \\
\text { more about FC } \\
(50 \%) \text {, and students } \\
\text { were willing to use } \\
\text { videos and } \\
\text { technology in the } \\
\text { learning process } \\
(60 \%) .\end{array}$ & $\begin{array}{l}\text { Students' perceptions about } \\
\text { FC were reserved. } \\
\text { insufficient amount of time } \\
\text { to prepare for it, because } \\
\text { they were more accustomed } \\
\text { to traditional-style lectures - } \\
\text { lack of faculty development }\end{array}$ \\
\hline $\begin{array}{c}\text { Gadbury-Amyot } \\
\text { CC et al. } \\
2017 \\
\text { USa [19] }\end{array}$ & - & $\begin{array}{l}\text { Prerecorded } \\
\text { lectures }\end{array}$ & - & $\begin{array}{l}\text { Clinical } \\
\text { dentistry }\end{array}$ & $\begin{array}{c}178 \\
84-\mathrm{SP} 14 \\
95-\mathrm{SP} 15\end{array}$ & $\begin{array}{c}72 \% \text { reported } \\
\text { watching all/more } \\
\text { than half of the } \\
\text { prerecorded lectures } \\
\text { versus } 62 \% \text { of the } \\
\text { SP } 14 . \\
\text { In the SP15 cohort, } \\
68 \% \text { used active } \\
\text { learning strategies } \\
\text { when, } \\
\text { watching the lectures } \\
\text { versus } 58.3 \% \text { of the } \\
\text { SP14 cohort. } \\
\text { The time of day they } \\
\text { watched the videos, } \\
7-11 \text { pm. } \\
\text { Both SP14 and SP } 15 \\
\text { students reported } \\
\text { being unlikely to } \\
\text { read assigned } \\
\text { materials prior to } \\
\text { coming to } \\
\text { class }\end{array}$ & $\begin{array}{l}\text { Course redesign appeared to } \\
\text { engage students in self- } \\
\text { directed active learning. } \\
\text { More work is needed to } \\
\text { examine strategies for } \\
\text { promoting study practices . }\end{array}$ \\
\hline $\begin{array}{l}\text { Nishigawa } \\
2017 \\
\text { Japan [20] }\end{array}$ & $\begin{array}{l}\text { Team based } \\
\text { learning } \\
\text { (TBL) }\end{array}$ & $\begin{array}{l}\text { Teaching material } \\
\text { through the e- } \\
\text { learning system }\end{array}$ & Tests (quiz) & $\begin{array}{c}\text { Fixed } \\
\text { prosthodontics }\end{array}$ & $\begin{array}{c}48 \\
\text { students } \\
\text { FL }=41 \\
\text { Control }=8\end{array}$ & $\begin{array}{c}\text { TBL classes had } \\
\text { slightly higher scores } \\
\text { than } \\
\text { flipped classroom } \\
\text { classes. } \\
\text { No significant } \\
\text { differences both } \\
\text { considered to be } \\
\text { highly satisfactory. }\end{array}$ & $\begin{array}{l}\text { Both TBL and FC were } \\
\text { effective, with TBL } \\
\text { superseded the FC }\end{array}$ \\
\hline
\end{tabular}


(Table $\square$ ) contd.....

\begin{tabular}{|c|c|c|c|c|c|c|c|}
\hline Author & Control & $\begin{array}{c}\text { Out of } \\
\text { Classroom } \\
\text { Method }\end{array}$ & $\begin{array}{c}\text { In Class Time } \\
\text { Method }\end{array}$ & Specialty & $\begin{array}{c}\text { Number } \\
\text { of } \\
\text { Subjects }\end{array}$ & Outcome/Results & Suggestions/Conclusion \\
\hline $\begin{array}{l}\text { Seo CW et al. } \\
2018 \\
\text { Korea [21] }\end{array}$ & - & $\begin{array}{c}\text { You tube platform. } \\
\text { Micro lectures of } \\
20 \text { min each } \\
\text { (additional- } \\
\text { treatment/surgery } \\
\text { fields through } \\
\text { Google } \\
\text { Cardboard virtual } \\
\text { reality (VR) and } \\
\text { live surgery } \\
\text { broadcasting }\end{array}$ & $\begin{array}{c}\text { Group } \\
\text { Discussion }\end{array}$ & Periodontics & 69 & \begin{tabular}{|} 
YouTube is a \\
suitable platform that \\
facilitates self- \\
directed learning in \\
flipped classroom. \\
$82.6 \%$ student \\
adjudged the Video \\
in you tube is better \\
to learn than the \\
classroom.
\end{tabular} & $\begin{array}{l}\text { Research on various } \\
\text { platforms for learners to be } \\
\text { done and FC will eventually } \\
\text { be successfully integrated } \\
\text { into dental education }\end{array}$ \\
\hline $\begin{array}{l}\text { Lee } \mathrm{C} \text { and } \mathrm{Kim} \\
\text { SW } 2018 \\
\mathrm{USa}[22]\end{array}$ & $\begin{array}{l}\text { Traditional } \\
\text { classroom }\end{array}$ & \begin{tabular}{|} 
23-minute short \\
video lecture with \\
an annotated \\
Power Point \\
presentation
\end{tabular} & Quiz & \begin{tabular}{c|} 
Periodontal \\
Diagnosis and \\
Treatment \\
Planning
\end{tabular} & 71 & \begin{tabular}{|} 
Student quiz score \\
improved in flipped \\
classroom. \\
$84 \%$ of the students \\
agreed or strongly \\
agreed FC was \\
effective for learning \\
periodontal DTP
\end{tabular} & $\begin{array}{l}\text { For effective FC sessions, } \\
\text { faculty development is } \\
\text { essential }\end{array}$ \\
\hline $\begin{array}{c}\text { Elledge R et al. } \\
2018 \\
\text { Uk [23] }\end{array}$ & $\begin{array}{l}\text { Traditional } \\
\text { classroom }\end{array}$ & $\begin{array}{c}\text { e-learning } \\
\text { resource - virtual } \\
\text { learning } \\
\text { environment } \\
\text { (VLE) }\end{array}$ & $\begin{array}{l}\text { An interactive } \\
\text { tutorial } \\
\text { based on the } \\
\text { problems and } \\
\text { learning } \\
\text { objectives they } \\
\text { had identified }\end{array}$ & $\begin{array}{c}\text { Maxillofacial } \\
\text { radiology }\end{array}$ & $\begin{array}{l}\mathrm{FC}=10 \\
\mathrm{TC}=14\end{array}$ & $\begin{array}{c}\text { There was no } \\
\text { difference in } \\
\text { answering for the } \\
\text { single best answer } \\
\text { quiz before and after } \\
\text { the flipped classroom } \\
\text { and traditional } \\
\text { classroom group. } \\
\text { Student feedback } \\
\text { was positive with the } \\
\text { flipped classroom, } \\
\text { preferred flipped } \\
\text { than traditional } \\
\text { classroom. }\end{array}$ & $\begin{array}{l}\text { VLE as a stand-alone } \\
\text { educational intervention or } \\
\text { as part of a "blended" } \\
\text { learning approach will need } \\
\text { to be compatible with } \\
\text { multiple devices. } \\
\text { self-directed, autonomous } \\
\text { andragogy (adult } \\
\text { education),is required where } \\
\text { flexibility and accessibility } \\
\text { will be important }\end{array}$ \\
\hline $\begin{array}{c}\text { Slaven CM et al. } \\
2019[24] \\
\text { USA }\end{array}$ & $\begin{array}{c}\text { Traditional } \\
\text { instruction } \\
\text { with videos } \\
\text { incorporated. } \\
\text { into the } \\
\text { presentation } \\
\text { (TIV), and } \\
\text { traditional } \\
\text { instruction } \\
\text { with lecture } \\
\text { only (TI) }\end{array}$ & $\begin{array}{c}\text { 20-minute } \\
\text { voiceover } \\
\text { PowerPoint } \\
\text { (Microsoft for } \\
\text { Mac 2011, } \\
\text { Version 14.6.4) }\end{array}$ & $\begin{array}{c}\text { Discussion in } \\
\text { small group and } \\
\text { quiz }\end{array}$ & $\begin{array}{l}\text { Pediatric } \\
\text { dentistry }\end{array}$ & \begin{tabular}{|}
96 \\
students \\
divided in \\
to 3 \\
groups
\end{tabular} & $\begin{array}{c}\text { Though there was no } \\
\text { difference in the quiz } \\
\text { answered between } \\
\text { the groups. in the } \\
\text { flipped classroom } \\
\text { students had slightly } \\
\text { higher satisfaction } \\
\text { scores on course } \\
\text { satisfaction and } \\
\text { module usefulness }\end{array}$ & $\begin{array}{l}\text { FC considered to be useful } \\
\text { for Less experienced } \\
\text { lecturers and lecturers who } \\
\text { struggle using traditional } \\
\text { methods, where they can } \\
\text { utilize more Interactive } \\
\text { method of learning that can } \\
\text { be equally effective to } \\
\text { traditional instruction } \\
\text { specially while teaching } \\
\text { topic such as BGT } \\
\text { (behavior guidance therapy) }\end{array}$ \\
\hline $\begin{array}{c}\text { Isherwood G et } \\
\text { al. } \\
2019 \\
\text { Uk [12] }\end{array}$ & $\begin{array}{l}\text { Traditional } \\
\text { classroom }\end{array}$ & $\begin{array}{c}\text { videos via a virtual } \\
\text { learning } \\
\text { environment }\end{array}$ & $\begin{array}{c}\text { Practical } \\
\text { assignment }\end{array}$ & Orthodontics & $\begin{array}{c}60 \\
\text { students, } \\
30 \text { in each } \\
\text { group }\end{array}$ & $\begin{array}{l}\text { No difference was } \\
\text { seen between the } \\
\text { group in both } \\
\text { management of } \\
\text { orthodontic } \\
\text { emergencies and } \\
\text { regular orthodontic } \\
\text { treatment. }\end{array}$ & $\begin{array}{c}\text { Videos encourage more } \\
\text { effective learning, improved } \\
\text { engagement, awareness of } \\
\text { learning needs. } \\
\text { FC resulted in comparable } \\
\text { examination performance } \\
\text { and improved levels of } \\
\text { satisfaction }\end{array}$ \\
\hline $\begin{array}{c}\text { Lundgren N et } \\
\text { al. } 2020 \\
\text { Sweden [25] }\end{array}$ & - & $\begin{array}{l}\text { Lecture, which is } \\
\text { accompanied by } \\
\text { reading } \\
\text { instructions or a } \\
\text { case }\end{array}$ & $\begin{array}{l}\text { seminars and } \\
\text { quiz }\end{array}$ & $\begin{array}{l}\text { Example given } \\
\text { of Periodontics } \\
\text { in Quiz }\end{array}$ & $\begin{array}{c}\text { Not } \\
\text { mentioned }\end{array}$ & \begin{tabular}{|} 
Higher levels of \\
activity, engagement, \\
and attendance \\
amongst the \\
students, and for the \\
first time in many \\
years according to \\
the course \\
evaluations
\end{tabular} & $\begin{array}{l}\text { FC seminar uses active and } \\
\text { cooperative learning } \\
\text { strategies- can be an active } \\
\text { part of new model of } \\
\text { learning MALMO model. } \\
\text { This is the right path and a } \\
\text { fruitful way of teaching and } \\
\text { learning in dental education } \\
\text { today }\end{array}$ \\
\hline
\end{tabular}




\begin{tabular}{|c|c|c|c|c|c|c|c|}
\hline Author & Control & $\begin{array}{c}\text { Out of } \\
\text { Classroom } \\
\text { Method }\end{array}$ & $\begin{array}{c}\text { In Class Time } \\
\text { Method }\end{array}$ & Specialty & \begin{tabular}{|c|}
$\begin{array}{c}\text { Number } \\
\text { of } \\
\text { Subjects }\end{array}$ \\
\end{tabular} & Outcome/Results & Suggestions/Conclusion \\
\hline $\begin{array}{l}\text { Bock A et al. } \\
2020 \\
\text { Germany [26] }\end{array}$ & - & $\begin{array}{l}\text { The e-learning } \\
\text { program was } \\
\text { implemented using } \\
\text { the existing } \\
\text { learning } \\
\text { management } \\
\text { system (e Media } \\
\text { Skills Lab) of } \\
\text { the Medical } \\
\text { Faculty (26.5 min } \\
\text { each video) }\end{array}$ & Quiz & $\begin{array}{c}\text { Oral and } \\
\text { Maxillofacial } \\
\text { Surgery }\end{array}$ & 21 & $\begin{array}{c}\text { Overall, the e- } \\
\text { learning program } \\
\text { was rated with a } \\
\text { mean (SD)score of } \\
1.86 . \\
\text { students felt well } \\
\text { prepared for the } \\
\text { clerkship and daily } \\
\text { clinical practice. }\end{array}$ & $\begin{array}{c}\text { Increased motivation to } \\
\text { study more using the FC. } \\
\text { For the surgical clerkship in } \\
\text { OMFS, surgical video } \\
\text { delivery via FC considered } \\
\text { to be more beneficial. } \\
\text { A special name "Flipped } \\
\text { OR "was suggested to teach } \\
\text { the surgical procedures } \\
\text { during the clerkship or } \\
\text { internship. }\end{array}$ \\
\hline $\begin{array}{c}\text { Qutieshat AS et } \\
\text { al. } \\
2020 \\
\text { Jordan [27] }\end{array}$ & $\begin{array}{l}\text { Traditional } \\
\text { classroom }\end{array}$ & $\begin{array}{l}\text { E-lectures ( } 31 \text { to } \\
79 \text { minutes) and } \\
\text { one to three recent } \\
\text { scientific articles } \\
\text { that covered } \\
\text { similar. } \\
\text { subjects to the e- } \\
\text { lectures }\end{array}$ & $\begin{array}{l}\text { Interactive } \\
\text { session as a } \\
\text { slideshow }\end{array}$ & $\begin{array}{c}\text { Conservative } \\
\text { dentistry }\end{array}$ & $\begin{aligned} 364 & =\mathrm{TC} \\
253 & =\mathrm{FC}\end{aligned}$ & $\begin{array}{l}\text { The students' overall } \\
\text { grades in the blended } \\
\text { learning cohort were } \\
\text { an average } 7.25 \\
\text { points higher than in } \\
\text { the control cohort. }\end{array}$ & $\begin{array}{l}\text { Students' perceptions were } \\
\text { positive and supported the } \\
\text { adoption of a blended } \\
\text { learning model in the course }\end{array}$ \\
\hline $\begin{array}{c}\text { Fadel HT et al. } \\
\text { 2021[28] } \\
\text { Saudi Arabia }\end{array}$ & $\begin{array}{l}\text { Traditional } \\
\text { classroom }\end{array}$ & $\begin{array}{l}\text { Pre }- \text { recorded } \\
\text { videos }\end{array}$ & $\begin{array}{c}\text { Interactive } \\
\text { discussions and } \\
\text { posing group } \\
\text { questions, with } \\
\text { the } \\
\text { implementation } \\
\text { of peer } \\
\text { instruction and } \\
\text { the utilization of } \\
\text { a } \\
\text { web-based } \\
\text { audience } \\
\text { response system }\end{array}$ & Periodontics & $\begin{array}{c}76 \\
\text { students }\end{array}$ & $\begin{array}{c}\text { No difference } \\
\text { between TC and FC } \\
\text { The mean pre- and } \\
\text { post-test scores were } \\
3.98 \pm 1 \text { and } 3.61 \pm 1 \\
\text { respectively }\end{array}$ & $\begin{array}{c}\text { A higher margin of } \\
\text { disagreement with the posed } \\
\text { statements was observed } \\
\text { with the FC which could } \\
\text { represent their refusal to } \\
\text { accept suddenly introduced } \\
\text { new teaching/learning } \\
\text { method }\end{array}$ \\
\hline $\begin{array}{c}\text { Kishimoto N et } \\
\text { al. } 2021 \\
\text { Canada [29] }\end{array}$ & - & $\begin{array}{l}\text { Pre }- \text { recorded } \\
\text { video }\end{array}$ & $\begin{array}{c}\text { Simulation } \\
\text { exercise }- \text { tele- } \\
\text { simulation }\end{array}$ & $\begin{array}{c}\text { Medical } \\
\text { emergencies }\end{array}$ & $\begin{array}{c}\text { Not } \\
\text { mentioned }\end{array}$ & $\begin{array}{l}\text { Improved learners' } \\
\text { comprehension and } \\
\text { resulted in positive } \\
\text { feedback via the } \\
\text { questionnaire. }\end{array}$ & $\begin{array}{l}\text { It is possible to remotely } \\
\text { learn medical emergency } \\
\text { management in dental } \\
\text { clinics using Zoom }\end{array}$ \\
\hline
\end{tabular}

\subsection{Secondary Outcome}

\subsubsection{Mode of Delivery in Out the Classroom}

The mode of delivery and time allocated for the out-ofclassroom activity forms an important determinant of the student's active participation and active learning. Among the articles selected, it was seen that several modes of delivery had been tried. Prerecorded video of the lectures was popular among the faculty [18, 19, 22, 24, 28, 29]. Youtube videos (micro lecture video not exceeding $20 \mathrm{~min}$ ) were used in 2 studies $[12,21]$. Few of the studies did not mention the exact mode of delivery, however, they have mentioned it as online material or e- lectures (presumed to be prerecorded video) [16, $17,20,23]$. In addition to this, in one of the studies, the clinical practice aspect was taught by providing linking the content of treatment/surgery fields through Google cardboard virtual reality (VR) and live surgery broadcasting [21]. A combination of virtual or E-resources was also used [25]. Few studies provided additional study material like case studies or journal articles. Two studies reported giving abstracts of the lectures loaded with PDF along with the videos [20] (Table 2).

\subsubsection{Mode of Delivery In-classroom Activity}

Creating and planning in-classroom activities is the responsibility of the faculty involved in FC. One has to be careful to avoid traditional classroom lecturing and create a traditional classroom environment. Most of the studies utilized interactive sessions and group discussions, followed by quizzes $[11,16,18,21,24,27]$. To analyze the effect of FC, pre and post-tests are being done $[11,16,17,20]$. The seminar is the next form of the in-class activities [25]. Seminar presentation was initiated by an individual quiz or group-based quiz and followed by a discussion about the topic for a clear understanding of the concept. In one of the studies, an interactive tutorial-based case scenario was discussed [28], followed by a quiz. In another study, interactive sessions were prepared beforehand and utilized as a slideshow [27]. One of the more innovative methods to learn a chairside clinical skill was the use of the simulation methods [29] (Table 2).

\subsection{Advantages}

Any newer mode of teaching-learning method is compared with the traditional classroom for ascertaining its advantages. Since most of the studies have utilized pre-recorded videos, students felt that they could see them at their convenient time 
(High mobility and flexibility). One of the studies quoted $7 \mathrm{pm}$ to $11 \mathrm{pm}$ as the common time they watched the videos [19]. Unlike the TC where they cannot ask to pause and replay the lecture, in FC, prerecorded video has this advantage [16]. They can increase or decrease the speed of the video, to learn with greater time efficiency. Further in-classroom activity, it can be utilized to learn the concept in a better way and also allowed to have group discussions and mentor guidance for an indepth learning [18]. The Youtube mode of out-of-classroom activity encouraged the student to search for similar videos on youtube, which helped in broadening their knowledge [21]. The flipped classroom is beneficial and can be easily introduced in some specialties like maxillofacial radiology, where there is the use of recognition of patterns, which lends itself to online learning with an image repository and problem-based approach [18]. FC helped engage the students more actively in the learning process [25]. Above all, In-classroom activity - group discussion helped to improve communication skill and leadership qualities [16]. One of the studies reported that FC helped the student, to analyze, synthesize and evaluate the course content and use their knowledge to construct a shared meaning, thus making sense of what they are learning [23].

\subsection{Limitations and Disadvantages}

As it was seen in the previous secondary outcome, $\mathrm{FC}$ was not considered a successful method, compared to other teaching-learning methods [23]. Similarly, some of the limitations and disadvantages have been pointed out. In one study, many of the participated students felt the need to devote extra time to go through the flipped classroom activity [16]. Video or mini lectures are created with the shortest possible time, often 20 minutes, which may not be sufficient to deliver all the required content of a topic [21]. Video may not be watched by the students, ensuring the same would be difficult [21]. Unavailability of teachers immediately for doubt clearance was considered to be another limitation [28]. In the transition from faculty-centered to learner-centered courses, students are pushed to take on more active and responsible roles, which students may resist [29]. On the faculty side, considerable time is required to prepare the video lectures at the primary preparation [24]. Funding to prepare the videos, devoting the staff for the same and infrastructure also may be required in addition [24]. Classrooms must be structured to facilitate small-group discussion with sufficient interaction among peers and instructors [16]. Faculty training is required to implement the newer form of teaching-learning method, which is considered to be essential for the successful outcome of FC [24]. Few studies pointed out the lack of Wi-Fi, unstable internet connection as one of the reasons for failure in this program [23] (Table 2).

\subsection{Student and Faculty Feedback/Satisfaction Level}

In most of the studies where $\mathrm{FC}$ was considered to be superior to the TC, the student satisfaction rate was much higher compared to offline lectures [20, 21]. It ranged from $72 \%$ to $90 \%[17,19]$. Many students felt that their active engagement in understanding the concept increased, which also helped in supplementary learning practice, which has widened their scope of learning. In most studies, students' preference was more towards the flipped classroom than that of the traditional classroom $[16,18]$. Students felt that FC encourages deeper learning, better retention, and confidence while doing the clinical procedures. However, in two studies, the sudden change from TC to FC was resisted by the students, which was reflected in their performance. Lack of time to prepare in a given period was also considered a drawback by the students [18] (Table 2).

\subsection{Bias in the Selected Studies}

Many of the studies' sample sizes were small (not mentioning the number of students to minimum 10 students) $[23,25,29]$. Only 3 studies reported a sufficient number of students both in the control and test group [16, 19, 27]. Many studies considered only flipped classrooms without having control [11, 17, 18, 21]. In a few studies, students' prior knowledge was not assessed, many studies are concerned with one typical dental school, so the result cannot be generalized. Most of the studies are being performed for the short-term outcome (one-time outcome). Out of the classroom activity and in-classroom activity were different in different studies, in such cases, common conclusion cannot be drawn Table 2.

\section{DISCUSSION}

Flipped Classroom is an innovative new method of teaching-learning. From the beginning of the introduction of this pedagogy in 2009, the concept grew consistently from 2011 to 2014 [30] and remains noticeably high (Google Trends, 2021). All the fields of education embraced this concept with open hand. Dental education too was not far behind [31]. With this, the amount of research in this field substantially increased, with many universities starting it as a part of their curriculum design [32]. At the present stage, flipped classroom is being adapted at all the levels of education, from preliminary school education to professional higher education (medical, dental, and other health care professional courses) [32, 33].

Clinical dentistry courses are important in the learning curve of a dental student [34]. Thus, learning and understanding the concept theoretically is very important to apply the same during clinical practice [35]. Cognitive skill is considered an important aspect in this [36]. TC with teachercentered learning may not be able to fulfill this completely, because there is lack of opportunity for a student to actively involve and engage themselves [37]. FC may be an alternative method to achieve this learning gap seen with the TC [38]. Thus, this mini-review was an attempt to explore more about FC in clinical dentistry.

According to the studied literature, FC was considered to be a superior method of learning in chosen clinical dentistry specialty. This has been proved in several other health professional courses too [39 - 42]. Most of the studies rated success based on the pre and post-test and compared to the traditional classroom [43, 44]. FC is a student-centered learning concept. Students get actively involved and, in the process, learn the concepts better and in-depth [45]. This naturally helps them perform better in the quiz, tests, and clinical scenarios [46]. The concept of "3P" $\mathrm{s}$ in the FC prepare 
(student prepare at home), practice (at class), and process (student further gains knowledge at home) are helpful to the students [47]. This helps the student to achieve the desired outcome with their efforts, peer support, and mentor guidance, at the same time avoids monotonous traditional classroom exposure [48]. However, failure to implement this activity systematically may lead the way to lose interest among the students, with an attempt to implement it again may be resisted by them [49]. It is clear from the studies in the literate of this review is that not all the FC were successful. Lack of guidance to students regarding the $\mathrm{FC}$, untrained faculty, lack of faculty development course, the sudden transition from the TC to FC are a few noted reasons for the failure. Any new system introduced into the academic activity to be planned considering the obstacles which may arise and action to be well planned [50]. A systematic way of implementing this activity is explained in Fig. (1). In this way, the success rate of this program can be enhanced.

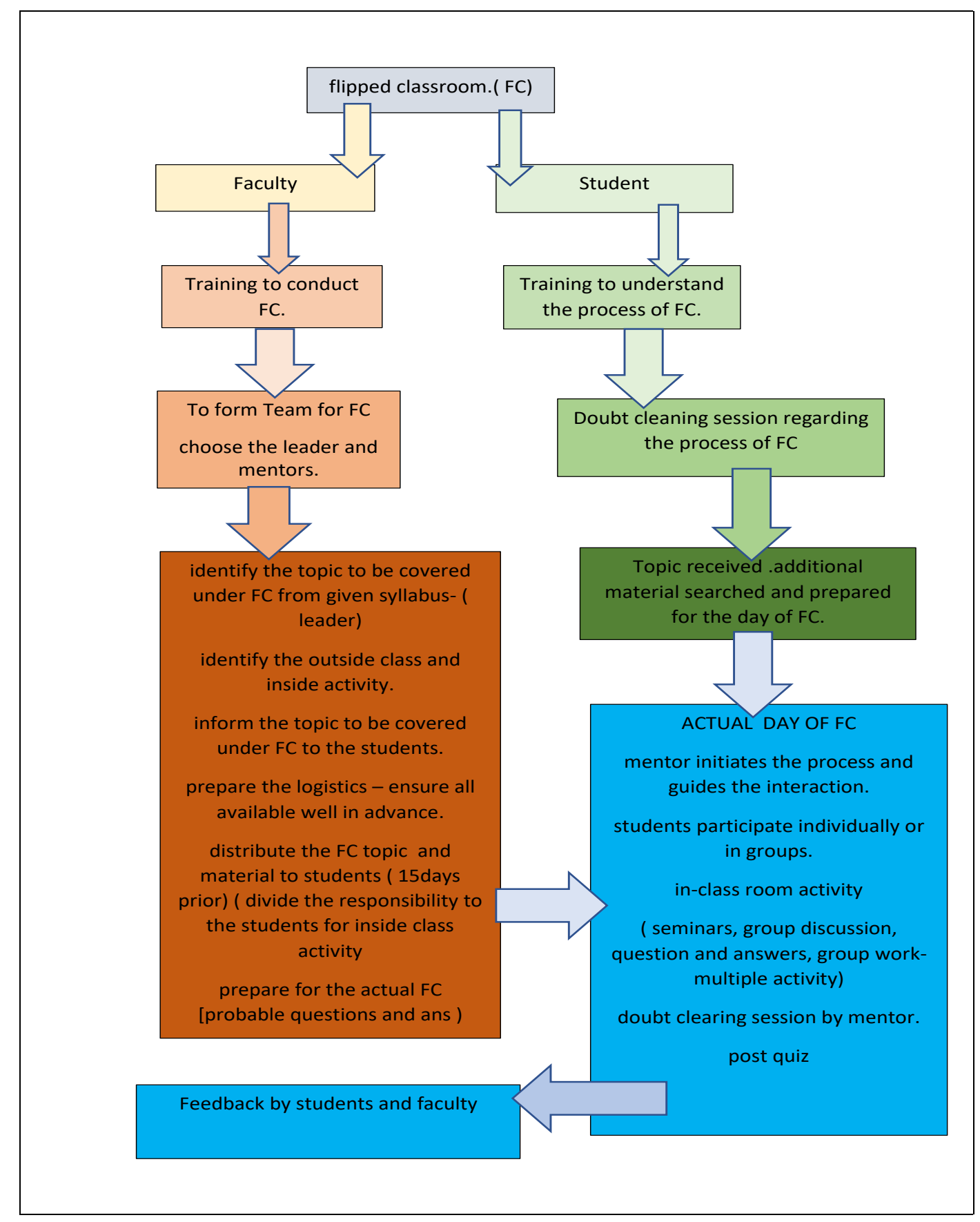

Fig. (1). Proposed model for the Flipped classroom. 
Outside classroom activity in many studies in this review was pre-recorded video lecture, which varied from 20 minutes to 70 minutes. Most of the studies presented videos of short duration (20 minutes), which is considered ideal in terms of student's concentration capacity (15 minutes) [4]. It often may not be sufficient to cover all the components desired to be delivered under that topic. Faculty has to be well trained in preparing this video in such a way that they could concise the topic within the given time and at the same time cover the content of the topic sufficiently [51]. Though the additional material was provided along with these videos, students unable to go through the same may be due to lack of time or because of the feeling of sufficiency after watching the video. This may block the intended use of FC for learning [52]. Ensuring that the students watch the video and go through the additional material is the responsibility of the faculty [51]. Students, active engagement needs to be enhanced, curiosity to explore further to be wakened up by faculty [51]. Though it is not an easy task, over a period of time, involvement in FC may change the faculty to get well adjusted to all these aspects [53]. Similarly, in-classroom activity to be created and planned well in advance in different ways, student's diversion out of the classroom is avoided like in TC. Small group discussion, group presentation seminars, dividing small tasks to each participant will ensure the greater participation of all the students in the class [54]. This also forces them to study and go through the given activity of the outside classroom activity without failure. Mentor responsibility in the inside classroom activity should confine to bring back the students on right track during discussion rather than presenting the complete concept as it is done in TC [55]. Quiz, both pre- and post-FC, is the old and most accepted method of assessment. It can activate acquired knowledge, increase motivation, and help the student to give feedback on how well they have learned the objectives of the associated case or study instructions given by the teacher [25]. It also helps to determine the level of student readiness for class activities. It can be a motivational factor, provided the marks are not considered for the evaluation [32]. Students' performance on the quizzes helped the instructor to identify any particular concepts where students fail to understand where the instructor can develop in-class exercises to address those issues [56]. Performance in the quiz was related to final summative exam scores. thus, it is considered a useful method of in-classroom activity in a flipped classroom [25, 32].

There is a certain specialty where images and photographs form an important part of the curriculum. For example, in maxillofacial radiology and maxillofacial surgery, images are essential for teaching. There are several online platforms for maxillofacial surgery that have been developed and are currently in use. e-FACE, (British Association of Oral and Maxillofacial Surgeons (BAOMS) in conjunction with Health Education England (HEE) e-Learning for Healthcare. (e-LH), is one among them [57]. There are further opportunities available to create such e- platforms, which can be made available for the students from a different specialty, which will help them to understand the concept easily.

The modifications and innovations in a flipped classroom are seen in all the health care education systems [25, 58 - 61]. Further, this methodology seems appropriate during a pandemic situation like COVID-19 [62, 63]. Flipped classrooms need not be a sole mode of pedagogy. It can be well combined with the other part of pedagogy [64].

All the topics and all the concepts cannot be taught in one way of pedagogy [65]. Selection of the topics, which demands higher cognitive skill to be identified and to be delivered through the alternative mode of learning like FC [66]. Teamwork with designated leaders and sub-leaders helps in creating the whole exercise fruitful and enjoyable both for the faculty and students $[67,68]$. Overall, a systematic, wellplanned FC is going to be successful without any doubt [69].

\section{CONCLUSION}

Within the limitation of this review, the flipped classroom is considered to be a successful model of pedagogy, provided both the students and faculty are trained to handle this well in advance. Any implementation of newer methods of teachinglearning has its advantages and disadvantages. Balancing this act is the responsibility of well-trained faculty in this arena. Each dental subject should incorporate, this method of training in the curriculum (partly) at the beginning of the year, so that, students and faculty are well prepared to absorb them and act appropriately. In this digital era, access to the large content of dental topics in various e-platforms challenges the traditional classroom model of pedagogy. Today's faculty in dentistry has a greater challenge in terms of delivery of topic due to the invasion of digital education platforms. Flipped classroom thus may help utilize the advantage of this and involve the student in their most comfortable mode of learning (online).

\section{LIST OF ABBREVIATIONS}

$$
\begin{array}{ll}
\text { FC } & =\text { Flipped Classroom } \\
\text { TC } & =\text { Traditional Classroom } \\
\text { PBL } & =\text { Problem-Based Learning } \\
\text { CBL } & =\text { Case-Based Learning } \\
\text { TBL } & =\text { Team-Based Learning } \\
\text { VR } & =\text { Google Cardboard Virtual Reality } \\
\text { BAOMS } & =\text { British Association of Oral and Maxillofacial Surgeons } \\
\text { HEE } & =\text { Health Education England } \\
\text { E-LfH } & =\text { E-Learning for Healthcare }
\end{array}
$$

\section{CONSENT FOR PUBLICATION}

Not applicable.

\section{FUNDING}

None.

\section{CONFLICT OF INTEREST}

The authors declare no conflict of interest, financial or otherwise.

\section{ACKNOWLEDGEMENTS}

The author would like to thank the Deanship of Scientific Research at Majmaah University for supporting this work.

\section{REFERENCES}

[1] Pyle MA. New models of dental education and curricular change: their potential impact on dental education. J Dent Educ 2012; 76(1): 89-97. 
[http://dx.doi.org/10.1002/j.0022-0337.2012.76.1.tb05237.x] [PMID: 22262553]

[2] Chugh R. E.-learning tools and their impact on pedagogy. Emerging paradigms in commerce and management education. Patiala, India: GSSDGS Khalsa College Press 2010; pp. 58-81.

[3] Tran B. Educational experiences with traditional, online and hybrid learning environments. Educ J 2016; 3(3) Available from: http://www.jespnet.com/journals/Vol_3_No_3_September_2016/8.pdf

[4] Hartley J, Davies IK. Note-taking: A critical review. Program Learn Educ Tech 1978; 15: 207-24.

[http://dx.doi.org/10.1080/0033039780150305]

[5] ADEA. Critical thinking skills toolbox. Available from: https://www.adea.org/adeacci/Resources/Critical-Thinking-SkillsToolkit/Pages/default.aspx

[6] Barrios-Penna CA, Torres-Martínez PA, Fernández-Sagredo M, DíazNarváez VP, AravenaGaete ME, Fonseca Molina J. Learning style variation in chilean dentistry students from the first to the fifth year. Revista Salud Uninorte 2018; 34(2): 323-37. [http://dx.doi.org/10.14482/sun.34.2.617.6]

[7] Haley CM, Brown B, Koerber A, Nicholas CL, Belcher A. Comparing case-based with team-based learning: Dental students' satisfaction, level of learning, and resources needed. J Dent Educ 2020; 84(4): 486-94.

[http://dx.doi.org/10.21815/JDE.019.190] [PMID: 32314392]

[8] Graham CR. Blended learning models. Encyclopedia of Information Science and Technology. $2^{\text {nd }}$ ed. IGI Global 2009; pp. 375-82. [http://dx.doi.org/10.4018/978-1-60566-026-4.ch063]

[9] Hew KF, Lo CK. Flipped classroom improves student learning in health professions education: a meta-analysis. BMC Med Educ 2018; 18(1): 38 .

[http://dx.doi.org/10.1186/s12909-018-1144-z] [PMID: 29544495]

[10] Tang F, Chen C, Zhu Y, et al. Comparison between flipped classroom and lecture-based classroom in ophthalmology clerkship. Med Educ Online 2017; 22(1): 1395679.

[http://dx.doi.org/10.1080/10872981.2017.1395679] [PMID: 29096591]

[11] Bohaty BS, Redford GJ, Gadbury-Amyot CC. Flipping the classroom: assessment of strategies to promote student-centered, self-directed learning in a dental school course in pediatric dentistry. J Dent Educ 2016; 80(11): 1319-27.

[http://dx.doi.org/10.1002/j.0022-0337.2016.80.11.tb06217.x] [PMID: 27803204]

[12] Isherwood G, Taylor K, Burnside G, Fitzgerald R, Flannigan N. Teaching orthodontic emergencies using the "flipped classroom" method of teaching-A mixed methods RCT. Eur J Dent Educ 2020; 24(1): 53-62.

[http://dx.doi.org/10.1111/eje.12467] [PMID: 31518475]

[13] Gianoni-Capenakas S, Lagravere M, Pacheco-Pereira C, Yacyshyn J. Effectiveness and perceptions of flipped learning model in dental education: A systematic review. J Dent Educ 2019; 83(8): 935-45. [http://dx.doi.org/10.21815/JDE.019.109] [PMID: 31133621]

[14] Vanka A, Vanka S, Wali O. Flipped classroom in dental education: A scoping review. Eur J Dent Educ 2019; 213-26.

[15] Fine P, Leung A, Bentall C, Louca C. The impact of confidence on clinical dental practice. Eur J Dent Educ 2019; 23(2): 159-67. [http://dx.doi.org/10.1111/eje.12415] [PMID: 30585682]

[16] Kavadella A, Tsiklakis K, Vougiouklakis G, Lionarakis A. Evaluation of a blended learning course for teaching oral radiology to undergraduate dental students. Eur J Dent Educ 2012; 16(1): e88-95. [http://dx.doi.org/10.1111/j.1600-0579.2011.00680.x] [PMID: 22251359]

[17] Custer T. Using the flipped learning approach in an introduction to radiation physics course: a qualitative case study of student beliefs and perceptions. Radiol Sci Educ 2016; 21(1): 17-22.

[18] Zain-Alabdeen EH. Perspectives of undergraduate oral radiology students on flipped classroom learning. Perspectives 2017; 6(3): 135-9.

[19] Gadbury-Amyot CC, Redford GJ, Bohaty BS. C.; Redford, G.J; Bohaty, B.S.Dental students' study habits in flipped/blended classrooms and their association with active learning practices. J Dent Educ 2017; 81(12): 1430-5.

[http://dx.doi.org/10.21815/JDE.017.103] [PMID: 29196330]

[20] Nishigawa K, Omoto K, Hayama R, et al. Comparison between flipped classroom and team-based learning in fixed prosthodontic education. J Prosthodont Res 2017; 61(2): 217-22. [http://dx.doi.org/10.1016/j.jpor.2016.04.003] [PMID: 27185191]

[21] Seo CW, Cho AR, Park JC, Cho HY, Kim S. Dental students' learning attitudes and perceptions of YouTube as a lecture video hosting platform in a flipped classroom in Korea. J Educ Eval Health Prof 2018; $15: 24$.

[http://dx.doi.org/10.3352/jeehp.2018.15.24] [PMID: 30317831]

[22] Lee C, Kim SW. Effectiveness of a flipped classroom in learning periodontal diagnosis and treatment planning. J Dent Educ 2018; 82(6): 614-20.

[http://dx.doi.org/10.21815/JDE.018.070] [PMID: 29858258]

[23] Elledge R, Houlton S, Hackett S, Evans MJ. "Flipped classrooms" in training in maxillofacial surgery: preparation before the traditional didactic lecture? Br J Oral Maxillofac Surg 2018; 56(5): 384-7. [http://dx.doi.org/10.1016/j.bjoms.2018.04.006] [PMID: 29709383]

[24] Slaven CM, Wells MH, DeSchepper EJ, Dormois L, Vinall CV, Douglas K. Effectiveness of and dental student satisfaction with three teaching methods for behavior guidance techniques in pediatric dentistry. J Dent Educ 2019; 83(8): 966-72.

[http://dx.doi.org/10.21815/JDE.019.091] [PMID: 31085686]

[25] Lundgren N, Jönsson A, Lindberg P. An upgrade of the Malmö model by implementing case $\square$ based teaching and learning, in an undergraduate dental education. Eur J Dent Educ 2021; 25(4): 649-56. [http://dx.doi.org/10.1111/eje.12642]

[26] Bock A, Heitzer M, Lemos M, et al. "Flipped OR": a modified didactical concept for a surgical clerkship in Oral and Maxillofacial Surgery. Br J Oral Maxillofac Surg 2020; 58(10): 1245-50.

[http://dx.doi.org/10.1016/j.bjoms.2020.03.008] [PMID: 32222311]

[27] Qutieshat AS, Abusamak MO, Maragha TN. Impact of blended learning on dental students' performance and satisfaction in clinical education. J Dent Educ 2020; 84(2): 135-42.

[http://dx.doi.org/10.21815/JDE.019.167] [PMID: 32043588]

[28] Fadel HT, Khalifah AM, Znadah WA. Sudden introduction of a flipped classroom framework involving face-to-face and synchronous active learning strategies to undergraduate dental students: A quasiexperimental study. Proceedings of the 12th International Conference on Society and Information Technologies (ICSIT 2021).

[29] Kishimoto N, Nguyen BH, Tran SD, Seo K. Telesimulation training applying flipped classroom in the dental clinic for medical emergencies. J Dent Anesth Pain Med 2021; 21(2): 179-81. [http://dx.doi.org/10.17245/jdapm.2021.21.2.179] [PMID: 33880411]

[30] Zainuddin Z, Halili SH. Flipped classroom research and trends from different fields of study. International review of research in open and distributed learning 2016; 17(3): 313-40.

[http://dx.doi.org/10.19173/irrodl.v17i3.2274]

[31] Eachempati P, KS KK, Ismail AR. The flipped classroom in dental education-Learning beyond the four walls of the classroom. MedEdPublish 2018; 21: 7

[http://dx.doi.org/10.15694/mep.2018.0000042.1]

[32] Park SE, Howell TH. Implementation of a flipped classroom educational model in a predoctoral dental course. J Dent Educ 2015; 79(5): 563-70.

[http://dx.doi.org/10.1002/j.0022-0337.2015.79.5.tb05916.x] [PMID: 25941150]

[33] Birgili B, Seggie FN, Oğuz E. The trends and outcomes of flipped learning research between 2012 and 2018: A descriptive content analysis. J Comput Educ 2021.

[http://dx.doi.org/10.1007/s40692-021-00183-y]

[34] Chambers D. Learning curves: what do dental students learn from repeated practice of clinical procedures? J Dent Educ 2012; 76(3): 291-302.

[http://dx.doi.org/10.1002/j.0022-0337.2012.76.3.tb05258.x] [PMID: 22383597]

[35] Canadian Dental Association. Pursuing the career in dentistry. Available from: https://www.cda-adc.ca/en/becoming/becoming

[36] Alhamdani F. Dental students' views of their clinical cognitive skills: A qualitative study. J Oral Dent Res 2017; 23(52): 1-3.

[http://dx.doi.org/10.12816/0036367]

[37] Soltanimehr E, Bahrampour E, Imani MM, Rahimi F, Almasi B, Moattari M. Effect of virtual versus traditional education on theoretical knowledge and reporting skills of dental students in radiographic interpretation of bony lesions of the jaw. BMC Med Educ 2019; 19(1): 233.

[http://dx.doi.org/10.1186/s12909-019-1649-0] [PMID: 31238927]

[38] Fayaz A, Mazahery A, Hosseinzadeh M, Yazdanpanah S. Video-based learning versus traditional method for the preclinical course of complete denture fabrication. J Dent (Shiraz) 2015; 16(1)(Suppl.): 21-8. [PMID: 26106631]

[39] Ramakrishnan P, Yahya YB, Hasrol MN, Aziz AA. Blended learning: a suitable framework for e-learning in higher education. Procedia Soc 
Behav Sci 2012; 67: 513-26

[http://dx.doi.org/10.1016/j.sbspro.2012.11.356]

[40] van Vliet EA, Winnips JC, Brouwer N. Flipped-class pedagogy enhances student metacognition and collaborative-learning strategies in higher education, but the effect does not persist. CBE Life Sci Educ 2015; 14(3): ar26.

[http://dx.doi.org/10.1187/cbe.14-09-0141] [PMID: 26113628]

[41] Brewer R, Movahedazarhouligh S. Successful stories, and conflicts: A literature review on the effectiveness of flipped learning in higher education. J Comput Assist Learn 2018; 34(4): 409-16. [http://dx.doi.org/10.1111/jcal.12250]

[42] Al Zahrani AM. From passive to active: The impact of the flipped classroom through social learning platforms on higher education students' creative thinking. Br J Educ Technol 2015; 46(6): 1133-48. [http://dx.doi.org/10.1111/bjet.12353]

[43] McNally B, Chipperfield J, Dorsett P, et al. Flipped classroom experiences: student preferences and flip strategy in a higher education context. High Educ 2017; 73(2): 281-98.

[http://dx.doi.org/10.1007/s10734-016-0014-z]

[44] Crews T, Butterfield J. Data for flipped classroom design: Using student feedback to identify the best components from online and faceto-face classes. High Edu Stud 2014; 4(3): 38-47.

[http://dx.doi.org/10.5539/hes.v4n3p38]

[45] Persky AM, McLaughlin JE. The flipped classroom-from theory to practice in health professional education. Am J Pharm Educ 2017; 81(6): 101-4.

[http://dx.doi.org/10.5688/ajpe816118] [PMID: 28970602]

[46] Ahmed HO. Flipped learning as a new educational paradigm: An analytical critical study. Eur Sci J 2016; 12(10): 83-5.

[http://dx.doi.org/10.19044/esj.2016.v12n10p417]

[47] Luminous M, Schermbrucker I, Lyons M. Traditional and flipped classroom approaches delivered by two different teachers: the student perspective. Educ Inf Technol 2018; 23(2): 797-817. [http://dx.doi.org/10.1007/s10639-017-9636-8]

[48] Ramírez D, Hinojosa C, Rodríguez F. Advantages, and disadvantages of flipped classroom: STEM students' perceptions. 7th International Conference of Education, Research, and Innovation ICERI, Seville, Spain. 17-9.

[49] Rotella C, Cain J. Research, perspectives, and recommendations on implementing the flipped classroom. Am J Pharm Educ 2016; 80(2) [http://dx.doi.org/10.5688/ajpe80234]

[50] A wide. I.T.; Paynter, M. The impact of a flipped-classroom approach on the student learning experience. Comput Educ 2019; 1(128): 269-83.

[http://dx.doi.org/10.1016/j.compedu.2018.09.013]

[51] Gopalan C, Bracey G, Klann M, Schmidt C. Embracing the flipped classroom: the planning and execution of a faculty workshop. Adv Physio Edu 2018; 42(4): 648-54.

[http://dx.doi.org/10.1152/advan.00012.2018]

[52] Schmidt SM, Ralph DL. The flipped classroom: A twist on teaching. Contemporary Issues in Education Research (CIER) 2016; 9(1): 1-6.

[53] Sharma N, Lau CS, Doherty I, Harbutt D. How we flipped the medical classroom. Med Teach 2015; 37(4): 327-30. [http://dx.doi.org/10.3109/0142159X.2014.923821]

[54] Buil-Fabregá M, Martínez Casanovas M, Ruiz-Munzón N. Flipped classroom as an active learning methodology in sustainable development curricula. Sustainability 2019; 11(17): 4577.

[http://dx.doi.org/10.3390/su11174577]

[55] Long T, Cummins J, Waugh M. Use of the flipped classroom instructional model in higher education: instructors' perspectives. J Comput High Educ 2017; 29(2): 179-200.

[http://dx.doi.org/10.1007/s12528-016-9119-8]

[56] Cevikbas M, Kaiser G. Flipped classroom as a reform-oriented approach to teaching mathematics. ZDM Math Educ 2020; 52(7): $1-15$.

[http://dx.doi.org/10.1007/s11858-020-01191-5] [PMID: 33042289]

[57] Dixon J, Manzanares-Cespedes C, Davies J, et al. O $\square$ HEALTH EDU: A scoping review on the reporting of oral health professional education in Europe. Eur J Dent Educ 2021; 25(1): 56-77. [http://dx.doi.org/10.1111/eje.12577] [PMID: 32816383]

[58] Nanclares NH, Rodríguez MP. Students' satisfaction with a blended instructional design: The potential of" flipped classroom" in higher education. J Interact Media Educ 2016(1)

[http://dx.doi.org/10.5334/jime.397]

[59] Guo J, Santiago JM, Phillips PA, Kasley K. Combining flipped classroom and integrating entrepreneurially minded learning in DC circuit analysis and design course. 2019 ASEE Annual Conference \& Exposition. June 15-19; Tampa, Florida. 2019.

[60] Yu Z, Zhu Q. Schema theory-based flipped classroom model assisted with technologies. Int J Inform Communi Technol Educ 2019; 15(2): 31-48.

[http://dx.doi.org/10.4018/IJICTE.2019040103]

[61] Pierce R, Fox J. Vodcasts and active-learning exercises in a "flipped classroom" model of a renal pharmacotherapy module. Am J Pharm Educ 2012; 76(10): 196.

[http://dx.doi.org/10.5688/ajpe7610196] [PMID: 23275661]

[62] Latorre-Cosculluela C, Suárez C, Quiroga S, Sobradiel-Sierra N, Lozano-Blasco R, Rodríguez-Martínez A. Flipped Classroom model before and during COVID-19: Using technology to develop $21^{\text {st }}$ century skills. Interact Technol Smart Educ 2021; 18(2)

[http://dx.doi.org/10.1108/ITSE-08-2020-0137]

[63] Jia C, Hew KF, Bai S, Huang W. Adaptation of a conventional flipped course to an online flipped format during the COVID-19 pandemic: Student learning performance and engagement. J Res Technol Educ 2020; 3: 1-21.

[64] Birgili B, Seggie FN, Oğuz E. The trends and outcomes of flipped learning research between 2012 and 2018: A descriptive content analysis. J Comp Edu 2021; 9: 1-30.

[http://dx.doi.org/10.1007/s40692-021-00183-y]

[65] Whipp JL, Ferguson DJ, Wells LM, Iacopino AM. Rethinking knowledge and pedagogy in dental education. J Dent Educ 2000; 64(12): 860-6.

[http://dx.doi.org/10.1002/j.0022-0337.2000.64.12.tb03387.x] [PMID: 11197948]

[66] Peterson A, Dumont H, LaFonta M, Law N. Understanding innovative pedagogies: Key themes to analyze new approaches to teaching and learning. OECD Education Working Papers, No 172.

[http://dx.doi.org/10.1787/19939019]

[67] See S, Conry JM. Flip My Class! A faculty development demonstration of a flipped classroom. Curr Pharm Teach Learn 2014; 6(4): 585-8.

[http://dx.doi.org/10.1016/j.cptl.2014.03.003]

[68] McCollum BM, Fleming CL, Plotnikoff K, Skagen DN. Relationships in the Flipped Classroom. Can J Scholarsh Teach Learn 2017; 8(3): n3.

[http://dx.doi.org/10.5206/cjsotl-rcacea.2017.3.8]

[69] Carvalho H, McCandless M. Implementing the flipped classroom. Revista Hospital Universitário Pedro Ernesto 2014; 13: 4.

\section{C) 2021 Abdullah Aljabr}

This is an open access article distributed under the terms of the Creative Commons Attribution 4.0 International Public License (CC-BY 4.0), a copy of which is available at: https://creativecommons.org/licenses/by/4.0/legalcode. This license permits unrestricted use, distribution, and reproduction in any medium, provided the original author and source are credited. 